\title{
PEMANFAATAN METODE FUZZY SUGENO DALAM PEMILIHAN RATING SUPLIER PADA PT. PILAREN
}

\author{
${ }^{1}$ Surya, ${ }^{2}$ Hoga Saragih, ${ }^{3}$ Magit Fitroni \\ ${ }^{1}$ Program Magister Pasca Sarjana - STMIK Eresha \\ ${ }^{2,3}$ Dosen STMIK Eresha, Jl. Haji Samali No 51 - Kalibata, Jakarta Indonesia 12740 \\ Surya_hendra_putra@yahoo.com, hogasaragih@gmail.com, magit.fitroni@gmail.com
}

\begin{abstract}
Dalam dunia bisnis, proses pengambilan keputusan akan menjadi salah satu kunci yang mendasar dan penting dalam keberlangsungan perusahaan. Salah satu hal yang penting adalah dalam pemilihan supplier. supplier merupakan mitra bisnis yang memegang peranan penting dalam menjamin ketersediaan bahan baku yang dibutuhkan. Biaya bahan baku merupakan salah satu komponen penting dalam biaya produksi. Oleh karena itu pemilihan supplier merupakan keputusan yang penting. Karena pemilihan supplier yang tepat dapat menurunkan biaya pembelian sehingga dapat meningkatkan keuntungan dan daya saing perusahaan

Ada beberapa teknik yang dapat membantu dalam pemilihan supplier secara cepat akurat dan efesien, diantaranya dengan menggunakan sistem komputerisasi, salah satunya adalah dengan menggunakan Fuzzy Logic. Metode ini merupakan salah satu alternatif dalam mengatasi masalah pemilihan supplier. Dalam penelitian ini Sistem Pengambilan keputusan pemilihan supplier dilakukan dengan Berbasis Fuzzy Logic Sugeno Orde 0. Untuk menentukan nilai rating terhadap penawaran yang ada maka ditetapkan beberapa variabel Fuzzy, Himpunan fuzzy yang menjadi penentu, dimana nilai ini nantinya akan membantu dalam pengelompokan supplier sehingga dapat menentukan supplier terbaik yang sesuai terhadap penyediaan barang yang dibutuhkan.

Hasil dari penerapan pemilihan supplier dengan menggunakan metode Fuzzy Logic ini akan di buat pengukuran kemudian sistem aplikasi akan memberikan tingkat akurasi yang tinggi dalam merekomendasikan hasil dari pemilihan rating supplier. Oleh karena itu dapat disimpulkan bahwa Metode pemilihan suplier berbasis Fuzzy Logic efektif diterapkan pada pemilihan rating supplier terbaik.
\end{abstract}

Kata kunci: Fuzzy sugeno, Pemilihan Supplier,SPK

\section{INTRODUCTION}

Dalam dunia bisnis, proses pengambilan keputusan akan menjadi salah satu kunci yang mendasar dan penting dalam keberlangsungan perusahaan. Salah satu hal yang penting adalah dalam pemilihan supplier. supplier merupakan mitra bisnis yang memegang peranan penting dalam menjamin ketersediaan bahan baku yang dibutuhkan. Biaya bahan baku merupakan salah satu komponen penting dalam biaya produksi. Oleh karena itu pemilihan supplier merupakan keputusan yang penting. Karena pemilihan supplier yang tepat dapat menurunkan biaya pembelian sehingga dapat meningkatkan keuntungan dan daya saing perusahaan. Kebutuhan terhadap penyediaan bahan baku di perusahaan ini sangat tinggi, hal ini ditunjukan dari jumlah proyek yang dikerjakan pada setiap bulannya.
Keperluan akan bahan baku juga sangat tinggi. Hal ini juga yang menyebabkan banyaknya penawaran dari supplier-suplier baru yang masuk,

Penentuan pemilihan supplier dari segi biaya, waktu pengiriman dan system pembayaran yang berbeda-beda mengharuskan keputusan yang akan diambil perlu dirapatkan terlebih dahulu. Pihak yang terlibat dalam rapat internal antara lain departemen Procurement dan Departement Purchasing yang tidak jarang memakan waktu lama, bahkan harus dilakukan hampir seminggu 3 kali. Salah satu jenis sistem aplikasi yang sangat popular di kalangan manajemen perusahaan adalah Sistem Pengambilan keputusan (SPK) atau biasa dikenal dengan Decision Support System disingkat DSS, DSS bukan untuk menggantikan tugas-tugas manajer, tetapi untuk menjadi sarana penunjang bagi mereka. DSS sebenarnya merupakan implementasi teori-teori pengambilan keputusan yang telah diperkenalkan oleh ilmu-ilmu seperti operation research dan management 
science. Beberapa teknik yang telah dipergunakan dalam menyelesaikan Procurement Tasks, khususnya penyediaan barang, adalah teknik Fuzzy Expert dalam system pengambilan keputusan dengan tujuan untuk memudahkan penggunanya dalam melakukan pemilihan supplier. DSS menggunakan pendekatan fuzzy segeno orde 0 untuk pemilihan rating supplier terbaik. Studi kasus yang diambil adalah data permintaan dan penawaran pada perusahaan PT.Pilaren

Penelitian yang sudah pernah dilakukan yang berhubungan dengan penelitian ini adalah :

1. Penelitian yang dilakukan oleh Dewi, Sudana and Putra (2012) dengan judul Comparing Scoring and Fuzzy Logic Method for Teacher Certification DSS in Indonesia, IJCSI International Journal of Computer Science Issues, Vol. 9, Issue 6, No 2 tentang Penggunaan metode fuzzy dalam pemilihan ranting guru terbaik.

2. Penelitian yang dilakukan oleh Ari Sukma Firmanullah, (2013) dengan judul penerapan metode fuzzy dalam sistem pendukung keputusan pemilihan kamera DSLR, yaitu tentang Sistem Pendukung Keputusan (SPK) digunakan sebagai alat bantu bagi para pengambil keputusan untuk memperluas kapabilitas para pengambil keputusan, dengan menggunakan metode Fuzzy model Tahani, namun tetap tidak untuk menggantikan penilaian para pengambil keputusan

3. Niraj, Malay and Kumar, Shalendra (2011, p) dengan judul Modelling For Supplier through Fuzzy Logic, tentang Penggunaan metode Fuzzy dalam mengambil keputusan untuk memilih supplier dengan menggunakan metode Centre of Gravity (COG) pada proses defuzzifikasi.

4. Meimaharani, Listyorini (2014), dengan judul Analisis 42ystem inference fuzzy sugeno dalam menentukanharga penjualan tanah untuk pembangunan minimarket, mengalokasi harga penjualan tanah untuk dibangunkan minimarket. Pengolahan data menggunakan Inference Fuzzy Sugeno. Interface Fuzzy Sugeno outputnya berupa konstanta atau persamaan linier. Berdasarkan pengujian yang dilakukan dapat diketahui bahwa teknik kendali fuzzy mampu menghasilkan respon seperti yang diharapkan yaitu mampu menilai jarak jauh dekat yang menentukan harga dalam penjualan tanah untuk pembangunan minimarket.

5. Jayanti, Sherly dan Sri Hartati (2012) dalam jurnal IJCCS, Vol.6, No.1, January 2012, pp. 55 66 ISSN: 1978-1520, menggunakan Logika Fuzzy
Mamdani untuk mendukung Keputusan Seleksi Anggota Paduan Suara Dewasa. Dalam penelitiannya digunakan penalaran Logika Fuzzy Mamdani dalam pemrosesan data input dan output sehingga menghasilakn informasi pendukung berupa ranking dalam pengambilan keputusan untuk menentukan seseorang untuk menjadi anggota paduan suara dewasa.

6. Nasr, Rezaei dan Barmaki (2012) dalam International Journal of Computer Applications (0975 - 8887) Volume 59- No.7, December 2012 menggunakan Fuzzy Mamdani untuk pengambilan keputusan dalam menganalisis dan mengklasifikasi kualitas air tanah di propinsi Yazd -Iran. Dalam penelitiannya dapat diklasifikasikan air tanah dengan cara mengukur 60 sampel air tanah dengan memanfaatkan 10 parameter kimia. Hasil penelitiannya 20 sampel dengan tingkat didinginkan dengan tingkat kepastian 32.29 - 100\%, 20 sampel pada tingkat acceptable denngan tingkat kepastian $37.07-92 \%$ dan 20 sampel tidak dapat diterima dengan tingkat kepastian 3.33-88.78\%.

7. Penelitian yang dilakukan oleh Ahmed dan Ebrahim (2011) dengan judul A Fuzzy Decision Support System for Managementof Breast Cancer pada jurnal (IJACSA) International Journal of Advanced Computer Science and Applications,Vol. 2, No.3, March 2011 tentang Penerapan Fuzzy Logic yang memungkinkan para peng-ambil keputusan dalam menentukan supplier yang tepat untuk memenuhi kebutuhan customer dalam suatu perusahaan dengan menggunakan berbagai pendekatan defuzzifikasi yang berbeda, yaitu : Centre of Area, Centre of Maxima, Centre of Sum, Max Membership, Weighted Average.

\section{LANDASAN TEORI Sistem Pengambilan Keputusan (SPK)}

SPK atau Decision Support System (DSS) adalah system informasi yang membantu untuk mengidentifikasi kesempatan pengambilan keputusan atau menyediakan informasi untuk membantu pengambilan keputusan.

Dalam DSS terdapat tiga tujuan yang harus dicapai:

a. Membantu manager dalam pembuatan keputusan untuk memecahkan masalah semi terstruktur.

b. Mendukung keputusan manajer, dan bukan mengubah atau mengganti keputusan tersebut. 
c. Meningkatkan efektifitas manajer dalam pembuatan keputusan, dan bukan peningkatan efisiensi.

\section{Tujuan SPK}

Dalam SPK terdapat tiga tujuan yang harus dicapai, yaitu :

a. Membantu manajer dalam pembuatan keputusan untuk memecahkan masalah semi terstuktur.

b. Mendukung keputusan manajer, dan bukannya mengubah atau mengganti keputusan tersebut.

c. Meningkatkan efektivitas manajer dalam pembuatan keputusan, dan bukannya

meningkatkan efisiensi.

\section{Komponen Decision Support System}

Secara garis besar DSS dibangun oleh tiga komponen besar:

a. Database

Sistem database berisi kumpulan dari semua data bisnis yang dimiliki perusahaan, diperlukan data yang relevan dengan permasalahan yang hendak dipecahkan melalui simulasi.

b. Model Base

Model Base atau suatu model yang merepresentasikan permasalahan ke dalam format kuantitatif (model matematika sebagai contohnya).

c. Sofware System

selanjutnya disatukan dalam komponen ketiga (software system), setelah sebelumnya direpresentasikan dalam bentuk model yang "dimengerti" komputer . Contohnya adalah penggunaan teknik RDBMS (Relational Database Management System), OODBMS (Object Oriented Database Management System) untuk memodelkan struktur data. Sedangkan MBMS (Model Base Management System) dipergunakan untuk merepresentasikan masalah yang ingin dicari pemecahannya.

\section{SISTEM FUZZY (FUZZY SYSTEM)}

Logika fuzzy merupakan suatu cara untuk memetakan suatu ruang input ke dalam suatu ruang output. Logika fuzzy sangat fleksibel, memiliki toleransi terhadap data-data yang tidak tepat. Logika fuzzy memiliki derajat keanggotaan dalam rentang 0 (nol) hingga 1 (satu), berbeda dengan logika digital yang hanya memiliki dua nilai yaitu 1 (satu) atau $0(\mathrm{nol})$.

Terdapat tiga operator dasar yang diciptakan Zadeh yaitu operator AND, OR dan NOT. Operator AND merupakan operasi interseksi pada himpunan (min). Operator OR merupakan operasi union pada himpunan (max). Operator NOT merupakan operasi komplemen pada himpunan $(1-\mu \mathrm{A}(\mathrm{x}))$. Nilai keanggotaan baru sebagai hasil dari operasi 2 himpunan disebut a-predikat. Dan dalam fuzzy dapat dibangun bentuk fungsi keanggotaan berupa fungsi linier, gauss, segitiga, trapesium dan berbentuk bell (Kusumadewi, Purnomo 2010, p. 23-25).

Dalam sistem berbasis aturan fuzzy, Fuzzy Inferensi Sistem (FIS) merupakan suatu kerangka komputasi yang didasarkan pada himpunan fuzzy. Secara umum dalam Fuzzy Inferensi Sistem (FIS) terdapat tiga elemen dasar, yaitu: Fuzzyfication, Inference dan Defuzzyfication. Proses FIS dapat dilihat pada gambar berikut :

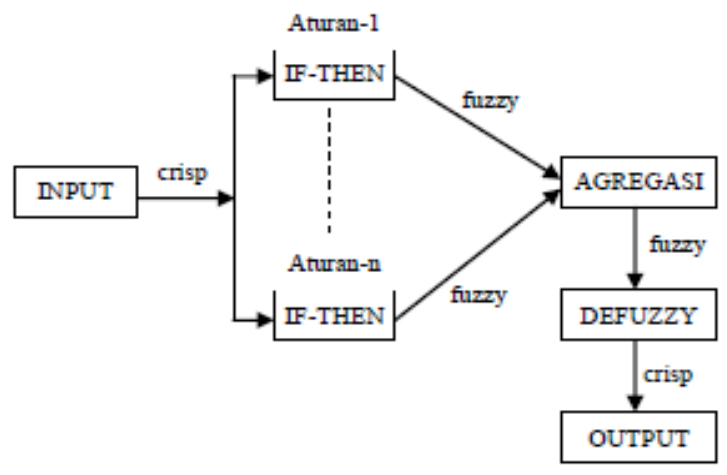

Gambar 1. Diagram Blok Sistem Inferensi Fuzzy

\section{a. Fuzzification}

Proses ini adalah menentukan derajat keanggotaan fuzzy, yaitu mengubah besaran tegas (crisp) ke besaran fuzzy. Masukan-masukan nilai kebenaran yang bersifat pasti (crisp input) dikonversi ke bentuk fuzzy input, yang berupa nilai linguistic yang semantiknya ditentukan berdasarkan fungsi keanggotaan.

Beberapa fungsi keanggotaan sederhana yang umum digunakan adalah

1. Fungsi Linier

$$
\begin{gathered}
\mu[x]=\left\{\begin{array}{cc}
0 ; & x \leq a \\
\frac{x-a}{b-a} ; & a \leq x \leq b
\end{array}\right. \\
\mu[x]=\left\{\begin{array}{cc}
\frac{b-x}{b-a} ; & a \leq x \leq b \\
0 ; & x \geq b
\end{array}\right.
\end{gathered}
$$

2. Fungsi Segitiga 


$$
\mu[\pi]=\left\{\begin{array}{cc}
0 ; & (x \leq a) \cup(x \geq c) \\
\frac{x-a}{b-\alpha} ; & a \leq \pi \leq b \\
\frac{c-x}{c-b} ; & b \leq \pi \leq c
\end{array}\right.
$$

Rumus alternatif menggunakan min dan max:

$$
(x ; a, b, c)=\max \left(\min \left(\frac{x-a}{b-a}\right),\left(\frac{c-x}{c-b}\right), 0\right)
$$

3. Fungsi Trapesium

$$
\mu[x]=\left\{\begin{array}{cc}
0 ; & x \leq a \text { atau } x \geq d \\
\frac{x-a}{b-a} ; & a \leq x \leq b \\
1 ; & b \leq x \leq c \\
\frac{d-x}{d-c} ; & x \geq d
\end{array}\right.
$$

Rumus alternatif menggunakan min dan max:

$$
(x, a, b, c)=\max \left(\min \left(\frac{x-a}{b-a}, 1, \frac{d-x}{d-c}\right), 0\right)
$$

Fungsi Sigmoid

Fungsi keanggotaan yang yang digunakan adalah fungsi sigmoid. Dapat dibedakan menjadi kurva-S Naik serta kurva-S Turun.

$$
\begin{gathered}
S(x ; \alpha, \beta, \gamma)=\left\{\begin{array}{cc}
0 ; & x \leq \alpha \\
2\left(\frac{x-\alpha}{\gamma-\alpha}\right)^{2} ; & \alpha \leq x \leq \beta \\
1-2\left(\frac{\gamma-\alpha}{\gamma-\alpha}\right)^{2} ; & \beta \leq x \leq \gamma \\
1 ; & x \geq \gamma
\end{array}\right. \\
\mu(x)=S(x ; \alpha, \beta, \gamma) \\
\mu(x)=1-S(x ; \alpha, \beta, \gamma) \\
\mu(x)=\left\{\begin{array}{cc}
1 ; & x \leq \alpha \\
1-2\left(\frac{\gamma-\alpha}{\gamma-\alpha}\right)^{2} ; & \alpha \leq x \leq \beta \\
2\left(\frac{x-\alpha}{\gamma-\alpha}\right)^{2} ; & \beta \leq x \leq \gamma \\
0 ; & x \geq \gamma
\end{array}\right.
\end{gathered}
$$

Fungsi Bell

Terdapat banyak fungsi yang membentuk fungsi bell, tiga diantaranya adalah fungsi Pi, Beta, dan Gauss.

$$
\mu(x)=\Pi(x ; \beta, \gamma)= \begin{cases}S\left(x ; \gamma-\beta, \gamma-\frac{\beta}{2}, \gamma\right) ; & x \leq \gamma \\ S\left(x ; \gamma, \gamma+\frac{\beta}{2}, \gamma+\beta\right) ; & x>\gamma\end{cases}
$$

Pada proses ini disusun aturan fuzzy dan dilakukan evaluasi untuk menghasilkan output dari tiap aturan. Input crisp dikirim ke basis pengetahuan yang berisi aturan-aturan fuzzy dalam bentuk if-then. Kemudian pada setiap aturan dicari nilai firestrength $(\alpha-$ predicate). Dengan langkah sebagai berikut:

1. Cari nilai firestrength ( $\alpha$-predicate),

a. jika digunakan operator AND untuk merelasikan nilai keanggotan dalam aturan fuzzy, maka:

$\alpha$-predicate $=\min (\mu 1(x) ; \mu 2(x) ; \mu \mathrm{n}(\mathrm{x}))$

b. jika digunakan operator OR untuk merelasikan nilai keanggotan dalam aturan fuzzy, maka:

$\alpha$-predicate $=\max (\mu 1(x) ; \mu 2(x) ; \mu n(x))$

2. Jika terdapat lebih dari satu aturan maka dilakukan agregasi dari semua aturan, dengan mencari nilai agregasi zn berdasarkan fungsi keanggotaan masingmasing. Ada beberapa metode untuk merepresentasikan hasil logika fuzzy diantaranya metode Mamdani dan Sugeno.

a. Model Mamdani

Metode Mamdani disebut juga dengan metode MAXMIN, karena pada metode Mamdani, aplikasi fungsi implikasi menggunakan MIN, sedangkan komposisi aturan menggunakan metode MAX. Inferensi output yang dihasilkan berupa bilangan fuzzy maka harus ditentukan suatu nilai crisp tertentu sebagai output. Proses ini dikenal dengan defuzzifikasi. Ada beberapa metode yang dipakai dalam defuzzifikasi antara lain metode centroid. Pada metode ini penetapan nilai crisp dengan cara mengambil titik pusat daerah fuzzy.

b. Model Sugeno

Metode Sugeno mirip dengan metode Mamdani, hanya output (konsekuen) tidak berupa himpunan fuzzy, melainkan berupa konstanta atau persamaan linier. Ada dua model metode Sugeno yaitu model fuzzy sugeno orde nol dan model fuzzy sugeno orde satu. Bentuk umum model fuzzy sugeno orde noll adalah :

IF ( $\mathrm{x} 1$ is $\mathrm{A} 1)$ o ( $\mathrm{x} 2$ is $\mathrm{A} 2)$ o ..... o ( $\mathrm{xn}$ is $\mathrm{An})$ THEN $\mathrm{z}$ $=\mathrm{k}$

Bentuk umum model fuzzy Sugeno orde satu adalah : IF ( $x 1$ is $A 1)$ o ( $x 2$ is $A 2)$ o ..... o ( $x n$ is $A n)$ THEN $\mathrm{z}=\mathrm{p} 1 . \mathrm{x} 1+\ldots \mathrm{pn} . \mathrm{xn}+\mathrm{q}$

\section{Defuzzification}

Proses defuzzyfcation mengubah kembali besaran fuzzy hasil dari inference engine, menjadi besaran tegas (crisp). Terdapat berbagai metode defuzzification yaitu: centroid method, height method, first (or last) of maxima, mean-max method dan weight method.

\section{Centroid Method}

\section{Inference}


Rumus yang digunakan adalah:

$$
y^{*}=\frac{\int y \mu_{R}(y) d y}{\int \mu_{R}(y) d y}
$$

jika nilai y berupa nilai diskrit, maka dapat digunakan rumus

$$
y^{*}=\frac{\sum y \mu_{R}(y)}{\sum \mu_{R}(y)}
$$

\section{(2.17)}

\section{Height Method}

Metode ini disebut juga metode keanggotaan maksimum, secara sederhana akan memilih nilai tegas (crisp) yang memiliki derajat keanggotaan maksimum.

3. First of Maxima/Last of Maxima Method

Pada metode ini fungsi keanggotaan output dapat memiliki lebih dari satu nilai maksimum, karena itu akan dipilih nilai maksimum pertama atau nilai maksimum terakhir, tergantung aplikasi yang dibuat.

4. Mean-Max Method

Metode ini juga merupakan generalisasi dari height method, namun akan memilih nilai tengah dari nilai tegas dengan derajat keanggotaan maksimum, dengan rumus :

$$
y^{n}=\frac{m+M}{2}
$$

$$
\mathrm{m}=\text { nilai tegas yang terkecil }
$$$$
\mathrm{M}=\text { nilai tegas yang terbesar }
$$

\section{Weighted Average Method}

Metode ini mengambil nilai rata-rata dengan menggunakan pembobotan yang diambil dari nilai derajat keanggotaan yang dapat dicari dengan rumus :

$$
y^{*}=\sum \frac{\mu(y) \cdot y}{\mu(y)}
$$

\section{Kerangka Pemikiran}

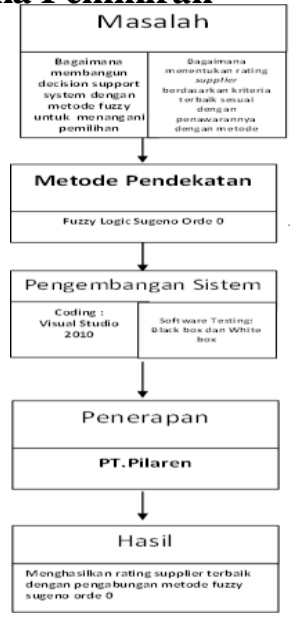

Gambar 2. Kerangka Pemikiran Penelitian

\section{Perancangan Penelitian}

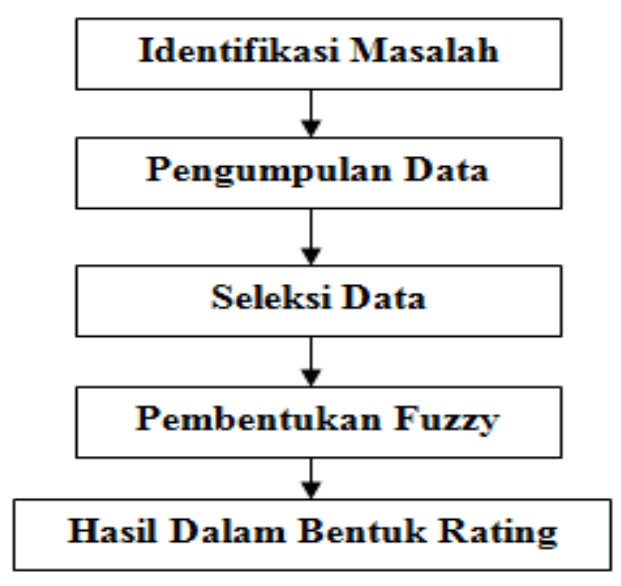

Gambar 3 : Skema analisis penyelesaian pemilihan supplier

\section{Seleksi Data}

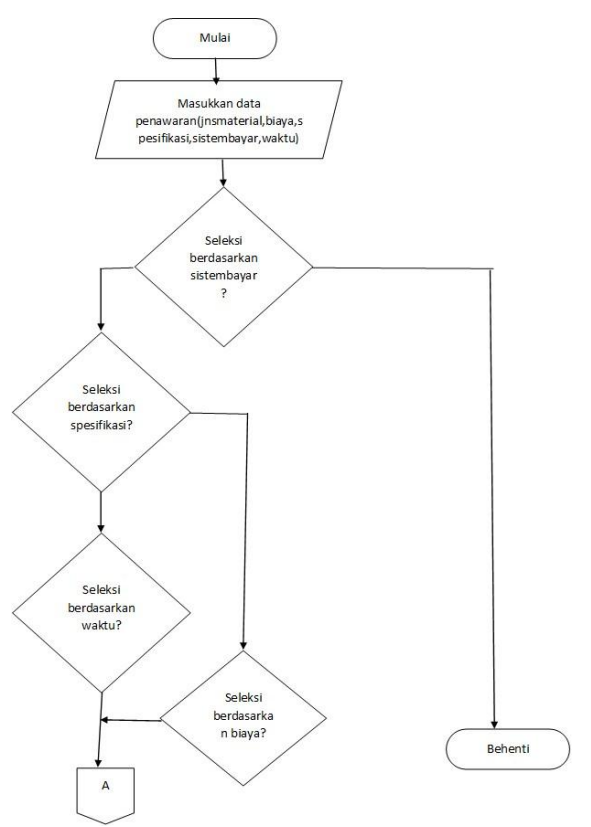

Gambar 4. Flowchart seleksi data

\section{Pembentukan System Fuzzy}




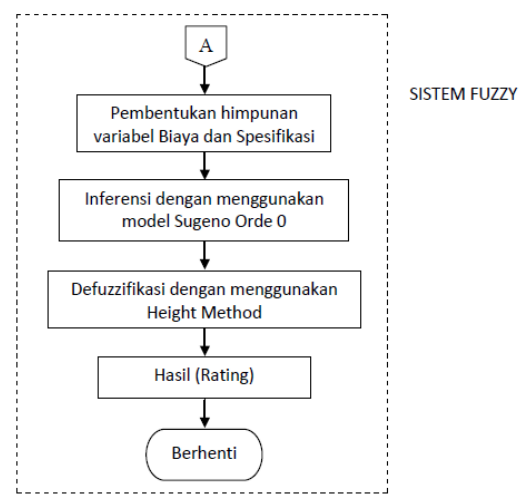

Gambar 5. Flowchart penentuan hasil menggunakan metode height method

\section{Himpunan Fuzzy}

Dalam hal ini variabel biaya yaitu : mahal, sedang, dan murah. Dikelompokan dengan metode klasifikasi/classification berdasarkan penawaran dari supplier dengan ketentuan sebagai berikut :

a. Biaya nilai batas terendah dalam himpunan variabel "murah". Biaya ${ }_{\text {murah }}=$ B0.

b. Biaya nilai batas tertinggi dalam himpunan variabel "mahal". Biaya ${ }_{\text {mahal }}=$ B4.

c. nilai batas terendah dan tertinggi ditetapkan sebagai nilai batas tengah dari himpunan variabel "sedang" dan juga merupakan nilai batas tertinggi dari himpunan variabel "murah" serta nilai batas terendah dari himpunan variabel "mahal".

nilai batas tengah Biaya ${ }_{\text {sedang }}$ adalah $\mathrm{B} 2=(\mathrm{B} 0+\mathrm{B} 4) /$ 2.

d. Nilai batas terendah dari himpunan variabel "sedang" merupakan nilai tengah dari nilai batas terendah dari himpunan variabel "murah" dengan nilai batas tengah himpunan variabel "sedang".

nilai batas terendah Biaya adalah $\mathrm{B} 1=(\mathrm{B} 0+\mathrm{B} 2) / 2$.

e. Nilai batas tertinggi dari himpunan variabel "sedang" merupakan nilai tengah dari nilai batas tertinggi dari himpunan variabel "mahal" dengan nilai batas tengah himpunan variabel "sedang".

nilai batas tertinggi Biaya ${ }_{\text {sedang }}$ adalah B3, maka nilai batas tertinggi Biaya ${ }_{\text {sedang }}$ atau $\mathrm{B} 3=(\mathrm{B} 4+\mathrm{B} 2) / 2$

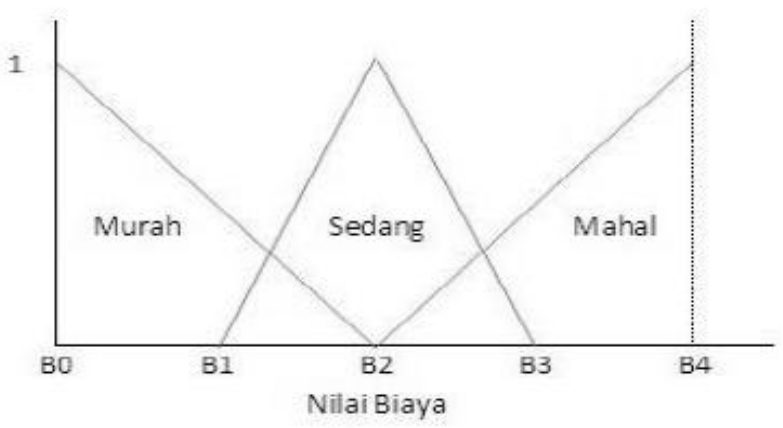

Gambar 6. Himpunan variabel biaya

Dengan derajat keanggotaan variabel biaya dapat dihitung dengan rumus sebagai berikut :

Himpunan variabel Biaya Murah

$$
\mu \text { Biaya }_{\text {murah }}[x]\left\{\begin{array}{c}
0 ; x \geq B 2 \\
\frac{B 2-x}{B 2-B 0} ; 0 \leq x \leq B 2
\end{array}\right.
$$

Dimana :

a) $x=$ biaya yang ditawarkan oleh supplier

b) $B 2=$ nilai tertinggi dalam himpunan variabel "murah"

c) $B O=$ nilai terendah dalam himpunan variabel "murah"

Himpunan variabel Biaya sedang

$$
\mu \text { Biaya }_{\text {sedang }}[x]\left\{\begin{array}{l}
0 ; x \leq B 1 \text { atau } x \geq B 3 \\
\frac{x-B 1}{B 2-B 1} ; B 1 \leq x \leq B 2 \\
\frac{B 3-x}{B 3-B 2} ; B 2 \leq x \leq B 3
\end{array}\right.
$$

Dimana :

a) $x=$ biaya yang ditawarkan oleh supplier

b) $B 1=$ nilai terendah dalam himpunan variabel "sedang"

c) $B 2$ = nilai tengah dalam himpunan variabel "sedang"

d) $B 3=$ nilai tertinggi dalam himpunan variabel "sedang"

Himpunan variabel Biaya mahal

$$
\mu \text { Biaya }_{\text {mahal }}[x]\left\{\begin{array}{c}
0 ; x \leq B 2 \\
\frac{x-B 2}{B 4-B 2} ; B 2 \leq x \leq B 4 \\
1 ; x \geq B 4
\end{array}\right.
$$

Dimana :

a) $x=$ biaya yang ditawarkan oleh supplier

b) $B 2=$ nilai terendah dalam himpunan variabel "mahal"

c) $B 4=$ nilai tertinggi dalam himpunan variabel "mahal"

variabel spesifikasi dapat dilihat pada gambar 7 


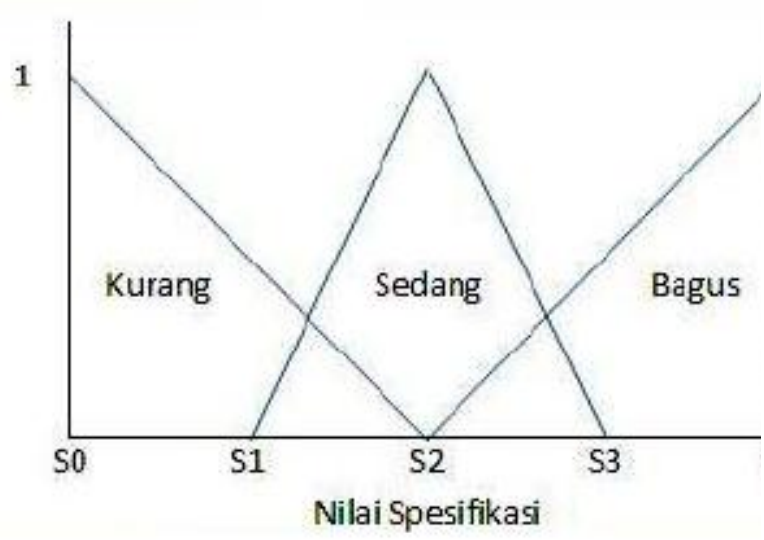

Gambar 7.Himpunan variabel spesifikasi derajat keanggotaan variabel spesifikasi dapat dihitung dengan menggunakan rumus sebagai berikut :

Himpunan variabel ukuran $n_{\text {kurang }}$

$$
\mu \text { Spesifikasi }_{\text {kurang }}[x]\left\{\begin{array}{c}
0 ; x \geq S 2 \\
\frac{S 2-x}{S 2-S 0} ; 0 \leq x \leq S 2
\end{array}\right.
$$

Dimana :

a) $x=$ nilai spesifikasi yang ditawarkan oleh supplier

b) $S 2$ = nilai terbagus dalam himpunan variabel "kurang"

c) $S O=$ nilai terendah dalam himpunan variabel "kurang"

Himpunan variabel ukuran $_{\text {kurang }}$

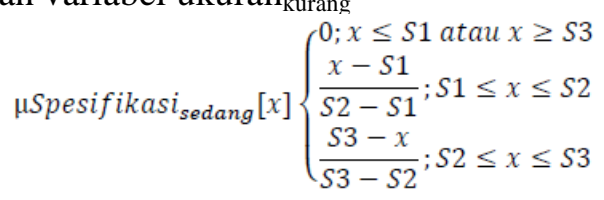

Dimana :

a) $x=$ nilai spesifikasi yang ditawarkan oleh supplier

b) $S 1=$ nilai terendah dalam himpunan variabel "sedang"

c) $S 2$ = nilai tengah dalam himpunan variabel "sedang"

d) $S 3$ = nilai terbagus dalam himpunan variabel "sedang"

$$
\begin{aligned}
& \text { Himpunan variabel spesifikasi bagus } \\
& \mu \text { Spesifikasi } i_{\text {bagus }}[x]\left\{\begin{array}{c}
0 ; x \leq S 2 \\
\frac{x-S 2}{S 4-S 2} ; S 2 \leq x \leq S 4 \\
1 ; x \geq S 4
\end{array}\right.
\end{aligned}
$$

Dimana :

a) $x=$ nilai spesifikasi yang ditawarkan oleh supplier

b) $S 2=$ nilai terendah dalam himpunan variabel "bagus"

c) $S 4$ = nilai terbagus dalam himpunan variabel "bagus"

\section{Aturan Fuzzy}

Untuk memperoleh rating penawaran berdasarkan variabel-variabel di atas maka dibentuk 9 (sembilan) aturan fuzzy sebagai berikut :
R1 : Jika Biaya "mahal" dan spesifikasi "kurang" maka rating "rendah".

R2 : Jika Biaya "sedang" dan spesifikasi "kurang" maka rating "rendah".

R3 : Jika Biaya "murah" dan spesifikasi "kurang" maka rating "sedang".

R4 : Jika Biaya "mahal" dan spesifikasi "sedang" maka rating "sedang".

R5 : Jika Biaya "sedang" dan spesifikasi "sedang" maka rating "sedang".

R6 : Jika Biaya "murah" dan spesifikasi "sedang" maka rating "sedang".

R7 : Jika Biaya "mahal" dan spesifikasi "bagus" maka rating "sedang".

R8 : Jika Biaya "sedang" dan spesifikasi "bagus" maka rating "sedang".

R9 : Jika Biaya "murah" dan spesifikasi "bagus" maka rating "tinggi".

\section{Inferensi Menggunakan Metode Sugeno Orde 0}

Model Sugeno menggunakan fungsi keanggotaan yang lebih sederhana. Setiap output yang dihasilkan oleh suatu nilai crisp tunggal digambarkan pada satu Singletone, yang memiliki derajat keanggotaan 1 (satu) pada suatu nilai crisp tunggal dan 0 (nol) pada semua nilai crisp yang lain. Dari aturan fuzzy di atas dapat dibuat fungsi singletone untuk rating penawaran seperti gambar 8 .

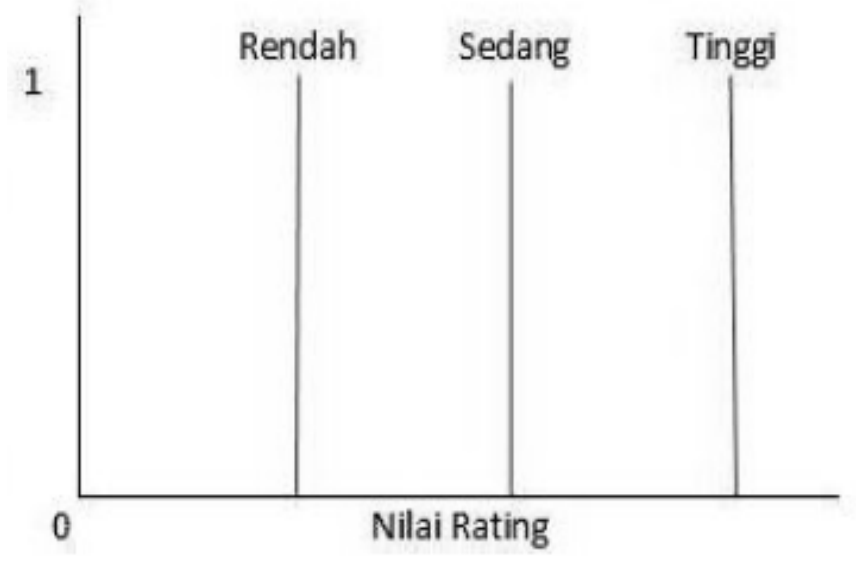

Gambar 8. Fungsi keanggotaan singletone untuk rating

Dalam hal ini rating dikelompokkan dalam 3 (tiga) nilai crisp tunggal, yaitu : "rendah", "sedang", dan "tinggi". Dimana dalam hal ini penulis menetapkan konstanstakonstanta sebagai berikut untuk mewakili nilai crisp tunggal tersebut : 

a) 1 (satu) pada nilai crisp "rendah"
b) 2 (dua) pada nilai crisp "sedang"
c) 3 (tiga) pada nilai crisp "tinggi"

\section{Proses Defuzzifikasi menggunakan Height Method}

Dengan menggunakan Height method pada proses defuzzyfikasi, maka nilai yang diambil dari seluruh fuzzy set yang terbentuk adalah nilai maksimumnya. Dari nilai maksimum ini rating penawaran diperoleh sehingga dapat ditentukan ranking dari masing-masing penawaran untuk menentukan supplier mana yang akan dipilih dalam menyelesaikan Procurement Tasks.

\section{Hasil}

Untuk mengimplementasikan penerapan metode-metode tersebut di atas, maka dilakukanlah proses ujicoba.

\section{Hasil Penerapan}

Tahap awal penerapan adalah dengan mengisi form material

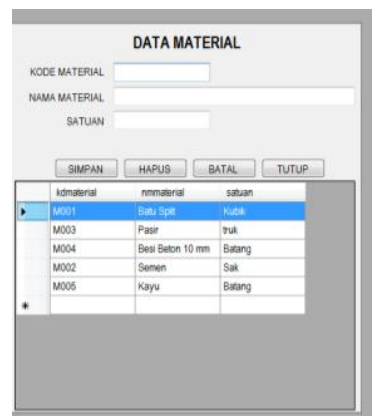

Gambar 9. Form pengisian material

Batasan Kriteria yang berlaku pada PT.Pilaren diinput kedalam Form batasan kriteria seperti terlihat pada gambar berikut

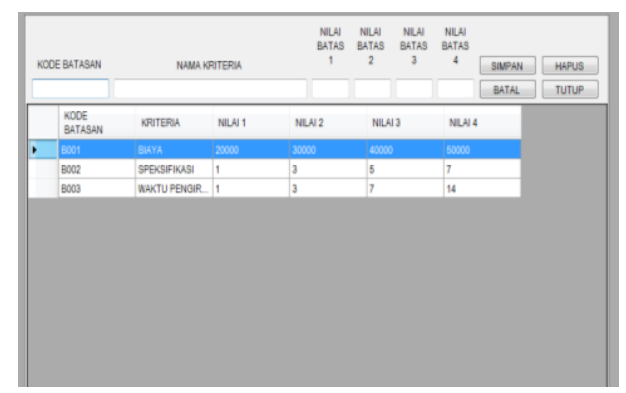

Gambar 10. Form Batasan Kriteria

\section{PEMBAHASAN}

Seleksi Tahap 1 berdasarkan waktu pengiriman adalah Waktu penyediaan yang ditentukan oleh PT.Pilaren adalah 30 (tiga puluh) hari, maka sistem akan menguji waktu penyediaan yang ditawarkan oleh para supplier dalam penawarannya.

1.PT. Indo Perdana : DT $=14$ hari $»$ lolos seleksi

2. Aksara Beton : DT $=15$ hari $»$ lolos seleksi

3. Citra Pannel : DT $=25$ hari $\gg$ lolos seleksi

4. Johor Indo Satria : DT $=25$ hari $\gg$ lolos seleksi

5. PT.Wica Karya : DT $=40$ hari $»$ tidak lolos seleksi

6. CV. Bina Karya : DT $=31$ hari $»$ tidak lolos seleksi

7. CV. Krain Sarana: DT $=25$ hari » lolos seleksi

8. Prima Hardware : DT $=21$ hari $»$ lolos seleksi

9. CV. Widana Waren : DT $=20$ hari » lolos seleksi

\section{Seleksi penawaran Tahap II}

Berdasarkan seleksi kelolosan yang diinginkan oleh PT.Pilaren, maka dilakukan pengecekan terhadap jumlah kelolosan yang terdapat pada penawaran yang telah lolos.

a. PT. Indo Perdana: memenuhi 2 (dua) dari 3 (tiga) spesifikasi yang diinginkan oleh PT.Pilaren

b. Aksara Beton : memenuhi 3 (tiga) dari 3 (tiga) spesifikasi yang diinginkan oleh PT.Pilaren

c. Citra Pannel : memenuhi 3 (tiga) dari 3 (tiga) spesifikasi yang diinginkan oleh PT.Pilaren

d. Johor Indo Satria : memenuhi 3(tiga) dari 3 (tiga) spesifikasi yang diinginkan oleh PT.Pilaren

e. CV. Krain Sarana : memenuhi 2 (dua) dari 3 (tiga) spesifikasi yang diinginkan oleh PT.Pilaren

f. Prima Hardware : memenuhi 3 (tiga) dari 3 (tiga) spesifikasi yang diinginkan oleh PT.Pilaren 
g. CV. Widana Waren: memenuhi 2 (dua) dari 3 (tiga) spesifikasi yang diinginkan oleh PT.Pilaren

a. Himpunan fuzzy untuk spesifikasi

1. Nilai spesifikasi yang paling kecil diperoleh ( penawaran $\mathrm{CV}$. Widana Waren dimana hanya $s$ dari spesifikasi yang ditawarkan memen persyaratan yang diminta oleh user. Maka nilai báas terendah dalam himpunan variabel "kurang" adalah 1 atau $\mathrm{S} 0=1$.

2. Nilai spesifikasi yang paling besar diperoleh dari penawaran Johor Indo Satria dan . CV. Krain Sarana dimana seluruh spesifikasi yang ditawarkan memenuhi persyaratan yang diminta oleh user. Maka nilai batas tertinggi dalam himpunan variabel "bagus" adalah 3 atau $\mathrm{S} 4=3$.

3. Nilai batas tengah dari himpunan variabel "sedang" dan juga merupakan nilai batas tertinggi dari himpunan variabel "kurang" serta nilai batas terendah dari himpunan variabel "bagus" yang dapat diketahui sebagai berikut :

$$
\begin{gathered}
\mathrm{S} 2 \quad=(\mathrm{S} 0+\mathrm{S} 4) / 2 \\
=(1+3) / 2 \\
=(4) / 2 \\
=2
\end{gathered}
$$

4. Nilai batas terendah dari himpunan variabel "sedang" merupakan nilai tengah dari nilai batas terendah dari himpunan variabel "kurang" dengan nilai batas tengah himpunan variabel "sedang" yang dapat diketahui sebagai berikut :

$$
\begin{aligned}
\mathrm{S} 1 & =(\mathrm{S} 0+\mathrm{S} 2) / 2 \\
& =(1+2) / 2 \\
& =1,5
\end{aligned}
$$

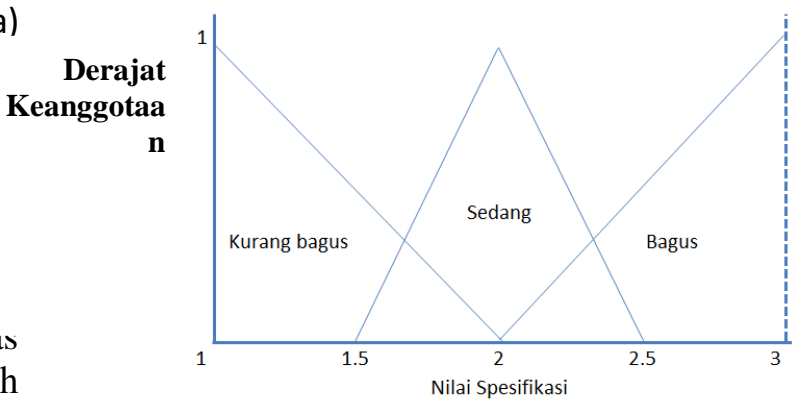

Derajat
Keanggotaan

Gambar 11. Hasil Fuzzifikasi Variabel Spesifikasi

Berdasarkan data penawaran yang telah lolos seleksi kedua, maka dihitung membership function dengan menggunakan rumus 3.4, 3.5, dan 3.6 dari setiap input dan dilanjutkan dengan penggunaan rumus 2.3 sebagai berikut :

i. PT. Indo Perdana dan $\mathrm{Cv}$. KS dengan nilai spesifikasi atau $\mathrm{x}=2$

$$
\begin{aligned}
& \mu \text { Spesifikasi } i_{\text {kurang }}[2]=\frac{2-2}{2-1} \\
& =0 \\
& \mu \text { Spesifikasi } i_{\text {sedang }}[2]=2-1,5 \\
& 2-1,5 \\
& =1 \\
& \mathrm{w}=\operatorname{AndMethod}(0 ; 1)=0 ; \text { Kurang }
\end{aligned}
$$

ii. $\mathrm{CV}$. Widana Waren dengan nilai spesifikasi atau $\mathrm{x}=$ 1

$$
\begin{gathered}
\mu \text { Spesifikasikurang }[1]=\underline{2-1} \\
2-1 \\
=1 \\
\mathrm{w}=\text { AndMethod }(1,-)=1 ; \text { kurang }
\end{gathered}
$$

5. Nilai batas tertinggi dari himpunan variabel "sedang" merupakan nilai tengah dari nilai batas tertinggi dari himpunan variabel "bagus" dengan nilai batas tengah himpunan variabel "sedang".

$\mathrm{S} 3=(\mathrm{S} 4+\mathrm{S} 2) / 2$

$$
\begin{aligned}
& =(3+2) / 2 \\
& =2,5
\end{aligned}
$$

Bentuk dari variabel spesifikasi dapat dilihat pada gambar 11 .

\section{3}

iii. $\mathrm{AB}, \mathrm{CP}, \mathrm{JIS}, \mathrm{PH}$ dengan nilai spesifikasi atau $\mathrm{x}=$

$$
\begin{aligned}
& \mu \text { Spesifikasi } i_{\text {bagus }}[3]=\frac{3-2}{3-2} \\
& =1 \\
& \mathrm{w}=\text { AndMethod }(-; 1)=1 \text {; Bagus }
\end{aligned}
$$

b. Himpunan fuzzy untuk Biaya

1. Nilai Biaya yang paling kecil diperoleh dari penawaran Aksara Beton maka nilai batas terendah dalam himpunan variabel "murah" adalah 245.800 atau $\mathrm{B} 0=245.800$.

2. Nilai Biaya yang paling besar diperoleh dari penawaran Cv.KS maka nilai batas tertinggi dalam himpunan variabel "mahal" adalah 263.200 atau B4 $=263.400$.

3. Nilai batas tengah dari himpunan variabel "sedang" dan juga merupakan nilai batas tertinggi dari 
himpunan variabel "murah" serta nilai batas terendah dari himpunan variabel "mahal" yang dapat diketahui sebagai berikut :

$$
\begin{aligned}
\mathrm{B} 2 & =(\mathrm{B} 0+\mathrm{B} 4) / 2 \\
& =(245.800+263.400) / 2 \\
& =254.600
\end{aligned}
$$

4. Nilai batas terendah dari himpunan variabel "sedang" merupakan nilai tengah dari nilai batas terendah dari himpunan variabel "murah" dengan nilai batas tengah himpunan variabel "sedang" yang dapat diketahui sebagai berikut :

$$
\begin{aligned}
\mathrm{B} 1 & =(\mathrm{B} 0+\mathrm{B} 2) / 2 \\
& =(245.800+254.600) / 2 \\
& =250.200
\end{aligned}
$$

5. Nilai batas tertinggi dari himpunan variabel "sedang" merupakan nilai tengah dari nilai batas tertinggi dari himpunan variabel "mahal"dengan nilai batas tengah himpunan variabel "sedang".

$$
\begin{aligned}
\mathrm{B} 3 & =(\mathrm{B} 4+\mathrm{B} 2) / 2 \\
& =(263.400+254.600) / 2 \\
& =259.000
\end{aligned}
$$

Bentuk dari variabel Biaya dapat dilihat pada gambar 12 di bawah ini.

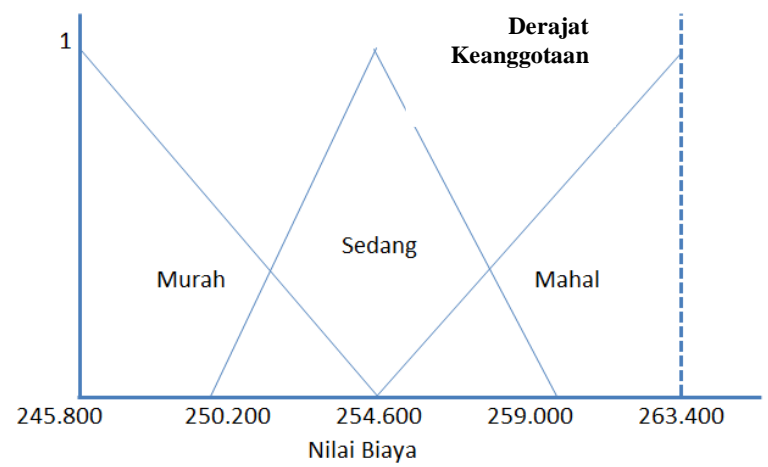

Gambar 12 Hasil Fuzzifikasi Variabel Biaya

Berdasarkan data penawaran yang telah lolos seleksi kedua, maka dihitung membership function dengan menggunakan rumus 3.1, 3.2, dan 3.3 dari setiap input dan dilanjutkan dengan penggunaan rumus 3.1 sebagai berikut :

i. PT $\mathrm{InP}$ dan $\mathrm{Cv}$.WW dengan nilai biaya atau $\mathrm{x}=$ 258.200

$$
\begin{aligned}
\mu \text { Biaya }_{\text {sedang }}[258.200] & =\frac{259.000-258.200}{259.000-250.200} \\
= & 0,09 \\
\mu \text { Biaya }_{\text {mahal }}[258.200] & =\frac{258.200-250.200}{263.400-254.600} \\
= & 0,90
\end{aligned}
$$

$\mathrm{w}=$ AndMethod $(0,09 ; 0,90)=0,09 ;$ Sedang ii. Aksara Beton dengan nilai Biaya atau $\mathrm{x}=245.800$

$$
\begin{gathered}
\mu \text { Biaya }_{\text {murah }}[245.800]=\frac{250.200-245.800}{250.200-245.800} \\
=1 \\
\mathrm{w}=\text { AndMethod }(1 ;-)=1 ; \text { murah }
\end{gathered}
$$

\begin{tabular}{|c|c|c|c|c|c|c|}
\hline $\begin{array}{l}\text { Nam } \\
\text { a } \\
\text { Supp } \\
\text { lier }\end{array}$ & $\begin{array}{l}\text { Har } \\
\text { ga }\end{array}$ & $\begin{array}{l}\text { Spesifi } \\
\text { kasi }\end{array}$ & $\begin{array}{l}\text { Nil } \\
\text { ai } \\
\text { W } \\
\text { Bia } \\
\text { ya }\end{array}$ & $\begin{array}{l}\text { Kate } \\
\text { gori } \\
\text { Biay } \\
\text { a }\end{array}$ & $\begin{array}{l}\text { Nilai } \\
\text { Spesifi } \\
\text { kasi }\end{array}$ & $\begin{array}{l}\text { Kateg } \\
\text { ori } \\
\text { Spesifi } \\
\text { kasi }\end{array}$ \\
\hline $\begin{array}{l}\text { PT.In } \\
\text { P }\end{array}$ & $\begin{array}{l}258 . \\
200\end{array}$ & 2 & $\begin{array}{l}0,0 \\
9 \\
\end{array}$ & $\begin{array}{l}\text { Seda } \\
\text { ng }\end{array}$ & 0 & $\begin{array}{l}\text { Kuran } \\
\mathrm{g}\end{array}$ \\
\hline $\mathrm{AB}$ & $\begin{array}{l}245 . \\
800\end{array}$ & 3 & 1 & $\begin{array}{l}\text { Mura } \\
\mathrm{h}\end{array}$ & 1 & Bagus \\
\hline $\mathrm{CP}$ & $\begin{array}{l}258 . \\
900 \\
\end{array}$ & 3 & $\begin{array}{l}0,0 \\
1 \\
\end{array}$ & $\begin{array}{l}\text { Seda } \\
\text { ng }\end{array}$ & 1 & Bagus \\
\hline JIS & $\begin{array}{l}258 . \\
900\end{array}$ & 3 & $\begin{array}{l}0,0 \\
1\end{array}$ & $\begin{array}{l}\text { Seda } \\
\text { ng }\end{array}$ & 1 & Bagus \\
\hline Cv.K & 263. & 2 & 1 & Maha & 0 & Kuran \\
\hline
\end{tabular}

iii. Citra Pannel dan Johor Indah S dengan nilai biaya atau $\mathrm{x}=258.900$

$$
\begin{gathered}
\begin{aligned}
\mu \text { Biay }_{\text {sedang }}[258.900] & =\frac{259.000-258.900}{259.000-250.200} \\
& =0,01
\end{aligned} \\
\begin{aligned}
\mu \text { Biay }_{\text {mahal }}[258.900] & =\frac{258.900-250.200}{263.400-254.600} \\
= & 0,98
\end{aligned} \\
\mathrm{w}=\text { AndMethod }(0,01 ; 0,98)=0,01 ; \text { Sedang }
\end{gathered}
$$

iv. Cv. KS dengan nilai Biaya atau $\mathrm{x}=263.400$

$$
\begin{array}{r}
\mu \text { Biay }_{\text {mahal }}[263.400]=\frac{263.400-254900}{263.400-254900} \\
=1 \\
\mathrm{w}=\text { AndMethod }(1,-)=1 ; \text { mahal }
\end{array}
$$

v. Prima Hardware dengan nilai Biaya atau $\mathrm{x}=248.700$

$$
\begin{gathered}
\mu \text { Biaya }_{\text {murah }}[248.700]=\frac{250.200-248.700}{250.200-248.700} \\
=1
\end{gathered}
$$$$
\mathrm{w}=\operatorname{AndMethod}(1 ;-)=1 ; \operatorname{murah}
$$

Berdasarkan hasil fuzzifikasi di atas diperoleh nilai firing strength (w) dari Penawaran yang lolos seleksi sebagai berikut :

Tabel 2

Hasil Firing Strength dari Penawaran yang lolos 


\begin{tabular}{|l|l|l|l|l|l|l|}
\hline S & 400 & & & 1 & & g \\
\hline PH & $\begin{array}{l}248 . \\
700\end{array}$ & 3 & 1 & $\begin{array}{l}\text { Mura } \\
\text { h }\end{array}$ & 1 & Bagus \\
\hline $\begin{array}{l}\text { Cv. } \\
\text { WW }\end{array}$ & $\begin{array}{l}258 . \\
200\end{array}$ & 1 & $\begin{array}{l}0,0 \\
9\end{array}$ & $\begin{array}{l}\text { Seda } \\
\text { ng }\end{array}$ & 1 & $\begin{array}{l}\text { Kuran } \\
\text { g }\end{array}$ \\
\hline
\end{tabular}

\section{Inferensi menggunakan metode Sugeno Orde 0}

Untuk mendapatkan fungsi keanggotaan pada rating penawaran dari tabel 4.6 diatas, hasil clipping dipilih derajat keanggotaan maksimum dari nilai-nilai linguistik yang dihubungkan dengan aturan Disjunction (v) berdasarkan aturan fuzzy yang ada.

i. PT. InP, $\mu$ Biaya $=(0,09$; Sedang $)$ dan $\mu$ Spesifikasi $=$ (0; Kurang)

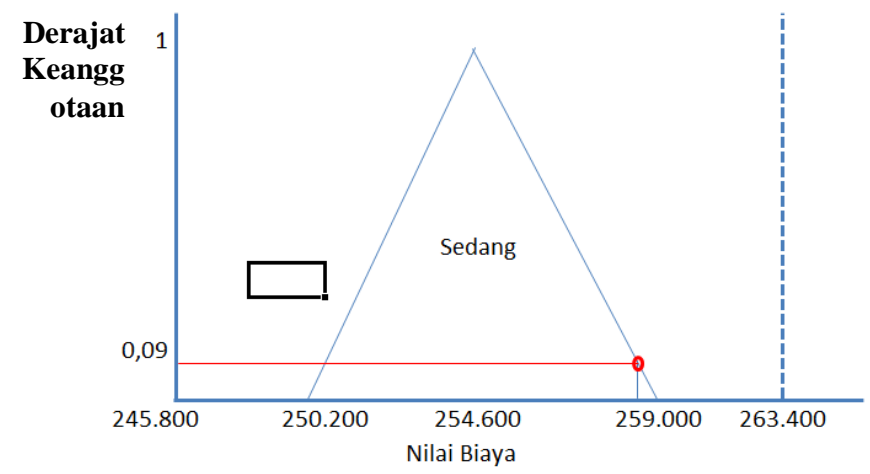

Gambar 13

Variabel Biaya terhadap penawaran dari PT. InP

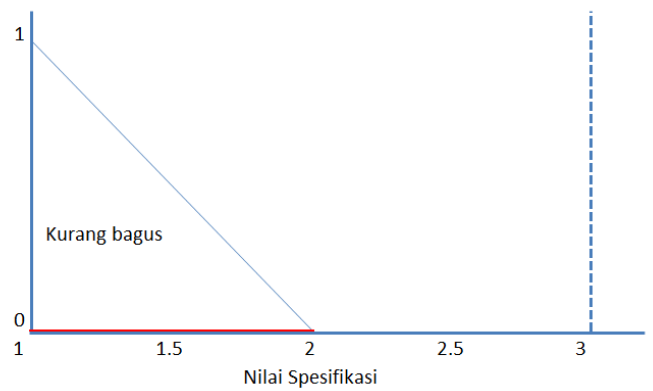

Gambar 14 Variabel Spesifikasi terhadap penawaran dari PT. InP

Maka output yang dihasilkan dari kedua variabel pada gambar 4.7 dan 4.8 adalah :

$$
\begin{aligned}
\mathrm{Z} & =\mathrm{OR}(0,09 ; 0) \\
& =0,09
\end{aligned}
$$

Dan memenuhi aturan fuzzy R2, sehingga output yang dihasilkan masuk dalam himpunan variabel "rendah", yang secara lebih jelas dapat dilihat pada gambar 15

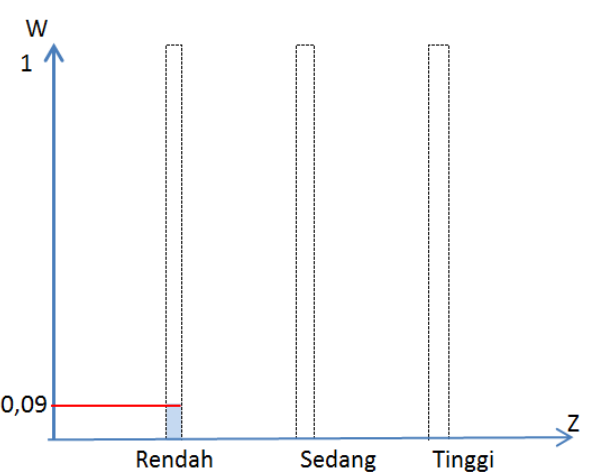

Gambar 15

Output penawaran dari PT. InP

ii. Dengan cara yang sama diperoleh output terhadap setiap penawaran yang telah difuzzifikasi sebagaimana tertera pada tabel 4.7 .

Tabel 3

\begin{tabular}{|c|c|c|c|c|c|c|}
\hline \multirow{2}{*}{$\begin{array}{c}\text { Nama } \\
\text { Suppli } \\
\text { er }\end{array}$} & \multicolumn{2}{|c|}{ wBiaya[x] } & \multicolumn{2}{|c|}{ wSpek[w] } & \multicolumn{2}{|c|}{$\mathbf{Z}$} \\
\hline & $\begin{array}{c}\text { Nil } \\
\text { ai }\end{array}$ & $\begin{array}{c}\text { Kateg } \\
\text { ori }\end{array}$ & $\begin{array}{c}\text { Nil } \\
\text { ai }\end{array}$ & $\begin{array}{c}\text { Kateg } \\
\text { ori }\end{array}$ & $\begin{array}{c}\text { Nil } \\
\text { ai }\end{array}$ & $\begin{array}{c}\text { Kateg } \\
\text { ori }\end{array}$ \\
\hline PT.InP & $\begin{array}{l}0,0 \\
9\end{array}$ & Sedang & 0 & Kurang & $\begin{array}{l}0,0 \\
9\end{array}$ & $\begin{array}{l}\text { Renda } \\
\mathrm{h}\end{array}$ \\
\hline $\mathrm{AB}$ & 1 & Murah & 1 & Bagus & 1 & Tinggi \\
\hline $\mathrm{CP}$ & $\begin{array}{l}0,0 \\
1\end{array}$ & Sedang & 1 & Bagus & $\begin{array}{l}0,0 \\
1\end{array}$ & Sedang \\
\hline JIS & $\begin{array}{l}0,0 \\
1\end{array}$ & Sedang & 1 & Bagus & $\begin{array}{l}0,0 \\
1\end{array}$ & Sedang \\
\hline Cv.KS & 1 & Mahal & 0 & Kurang & 1 & $\begin{array}{l}\text { Renda } \\
\mathrm{h}\end{array}$ \\
\hline $\mathrm{PH}$ & 1 & Murah & 1 & Bagus & 1 & Tinggi \\
\hline $\begin{array}{l}\text { Cv.W } \\
\mathrm{W}\end{array}$ & $\begin{array}{l}0,0 \\
9\end{array}$ & Sedang & 1 & Kurang & $\begin{array}{l}0,0 \\
9\end{array}$ & $\begin{array}{l}\text { Renda } \\
\mathrm{h}\end{array}$ \\
\hline
\end{tabular}

Hasil Inferensi

\subsubsection{Defuzzifikasi Menggunakan Height Method}

Metode yang digunakan dalam proses defuzzifikasi adalah Height Method, maka output yang dihasilkan dapat dilihat langsung dari jumlah nilai keanggotaan pada himpunan variabel yang terdapat pada table 4.7 dimana setiap nilai maksimum untuk setiap himpunan variabel adalah 1 (satu). Atau secara matematis dapat dihitung dengan cara mengurangi nilai rating maksimum yang dimiliki oleh setiap penawaran dengan derajat keanggotaan yang tidak dipenuhinya.

a. PT. InP, $\mathrm{z}=(0,09$; Rendah $)$, nilai rating maksimum $=2$, maka : 

$=0,09$

nilai rating $=1-(1-0,09)$

b. Dengan cara yang sama diperoleh output terhadap setiap output 4.8 .

penawaran sebagaimana tertera pada tabel

Tabel 4

Hasil Rating

\begin{tabular}{|c|c|c|c|c|c|}
\hline \multirow{2}{*}{$\begin{array}{c}\text { Nama } \\
\text { Suppli } \\
\text { er }\end{array}$} & \multirow{2}{*}{$\begin{array}{c}\begin{array}{c}\text { wBiaya } \\
{[\mathbf{x}]}\end{array} \\
\text { Nilai }\end{array}$} & \multirow{2}{*}{$\begin{array}{c}\text { wSpek[ } \\
\text { w] } \\
\text { Nilai }\end{array}$} & \multicolumn{2}{|c|}{$\mathbf{Z}$} & \multirow{2}{*}{$\begin{array}{c}\text { Nilai } \\
\text { Rati } \\
\text { ng }\end{array}$} \\
\hline & & & $\begin{array}{c}\text { Nilai } \\
\text { Outp } \\
\text { ut }\end{array}$ & $\begin{array}{c}\text { Nilai } \\
\text { Maksim } \\
\text { un }\end{array}$ & \\
\hline PT.InP & 0,09 & 0 & 0,09 & 1 & 0,09 \\
\hline $\mathrm{AB}$ & 1 & 1 & 1 & 3 & 2 \\
\hline $\mathrm{CP}$ & 0,01 & 1 & 0,01 & 2 & 1,01 \\
\hline JIS & 0,01 & 1 & 0,01 & 2 & 1,01 \\
\hline Cv.KS & 1 & 0 & 1 & 1 & 1 \\
\hline $\mathrm{PH}$ & 1 & 1 & 1 & 3 & 2 \\
\hline $\begin{array}{l}\text { Cv.W } \\
\text { W }\end{array}$ & 0,09 & 1 & 0,09 & 2 & 1,09 \\
\hline
\end{tabular}

Hasil yang terbaik adalah output yang mempunyai nilai tertinggi. Dalam artian, sangat disarankan untuk melakukan pembelian barang kepada supplier yang mempunyai nilai tertinggi tersebut.

Berdasarkan tabel di atas dapat output yang dihasilkan oleh setiap input yang telah lolos seleksi. Dimana seleksi ini dilakukan berdasarkan kriteriakriteria yang diinginkan oleh PT.Pilaren. Suatu input yang memiliki firing strength yang besar akan menjadi faktor yang akan dapat memberikan output yang besar. Tetapi firing strength bukan merupakan satu-satunya faktor dalam hal ini, aturan-aturan fuzzy terhadap masing-masing input juga memegang peranan yang sama pentingnya. Tidak akan mungkin ada suatu output apabila tidak ada suatu ketentuan yang mengatur tentang output yang akan dihasilkan.

Dalam hal ini kita dapat melihat bahwa semakin tinggi nilai firing strength dan nilai rating maka semakin baik output yang dihasilkannya.

Sebagaimana kita lihat pada tabel 4.8 di atas, firing strength maksimum ditemukan pada penawaran $\mathrm{AB}$, dan $\mathrm{PH}$ untuk kedua variabel, Spesifikasi dan Biaya. Dan output yang dihasilkan maksimum, dalam hal ini adalah 3 (tiga), karena output yang terbentuk berdasarkan aturan fuzzy dari kedua firing strength tersebut adalah "Tinggi". Berdasarkan aturan fuzzy yang ada, rating yang dihasilkan untuk kedua firing strength ini adalah "tinggi" sehingga output maksimum yang dihasilkan adalah 2 (Dua)".

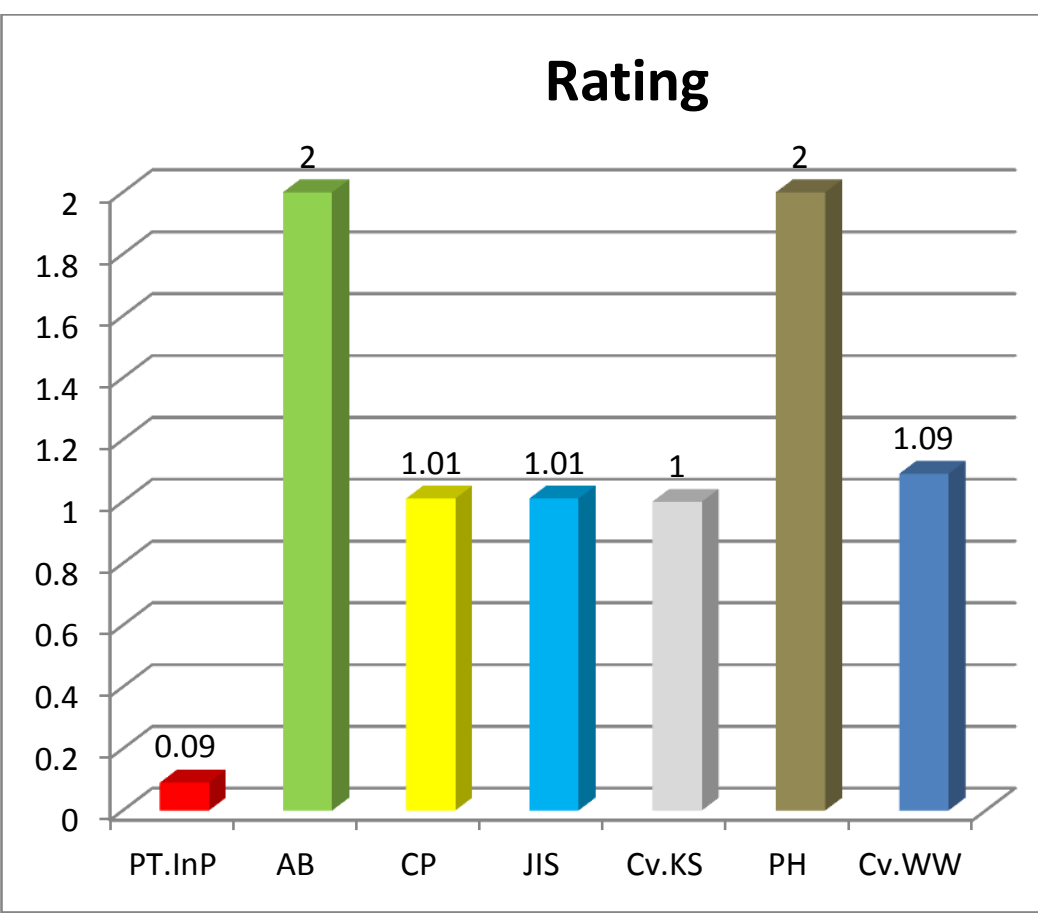

Gambar 16

Hasil Rating pemilihan Supplier dengan Fuzzy Logic

\subsection{Implikasi Penelitian}

Hasil penelitian ini memiliki implikasi secara manajeral, teknis dan teoritis, antara lain:

a. Manajerial, Implikasi bagi manajerial berpengaruh pula bagi perusahaan dan bagian procurement di perusahaan, yaitu:

Bagi Manajemen:

1. Dapat mengetahui hasil pemilihan suppplier secara lebih akurat

2. Memberikan masukan untuk pengambilan keputusan dalam pemilihan supplier yang tebaik berdasarkan kriteria-kriteria yang telah ditentukan

3. Meningkatkan efesiensi dalam proses procurement task

4. Memberikan keuntungan bagi perusahaan karena penghematan sumber daya dan cost pembelian

b. Teknis, secara teknis, penelitian ini memiliki implikasi terhadap pemilihan supplier yang sebelumnya menggunakan konvensional di ubah menjadi menggunakan sebuah aplikasi yang dapat menampilkan rating supplier terbaik yang diperoleh dari data-data penawaran dari supplier. 
c. Teoritis, secara teoritis, hasil penelitian ini memberikan implikasi bahwa Sistem DSS dengan metode Fuzzy Sugeno Orde 0 dapat membentuk sebuah rating supplier terbaik dengan variable delivery time, spesifikasi barang, dan juga harga barang.

\section{Kesimpulan}

Terdapat beberapa hal yang dapat diambil sebagai kesimpulan berdasarkan analisis yang telah dilakukan pada bab-bab sebelumnya adalah sebagai berikut :

a. DSS berbasis Fuzzy Logic ini dibangun dengan menggunakan bahasa pemograman Visual Studio 2010 dengan penanganan database menggunakan MySQL.

b. DSS untuk penentuan rating supplier terbaik dikembangkan dengan metode fuzzy logic sugeno orde 0 sehingga hasil akhir menghasilkan rating supplier terbaik yang disajikan dalam bentuk grafik.

c. Dalam menentukan ranting suplier dengan sistem pengambilan keputusan berbasis Fuzzy Logic Sugeno Orde 0 dimulai dari seleksi data sesuai dengan yang diingginkan berdasarkan variable waktu pengiriman, cara pembayaran dan biaya sesuai dengan ketentuan dan dibandingkan dengan penawaran dari supplier berdasarkan kriteria yang ada. Data yang lolos seleksi tahap pertama lanjut di seleksi berikutnya berdasrkan variable spesifikasi barang yang sama antara data permintaan dan penawaran. Data yang lolos seleksi maka proses selanjutnya adalah penerapan fuzzy logic sugeno orde 0 dengan variable biaya dan spesifikasi dari mulai fuzzyfikasi, inferensi, defuzzifikasi sehingga output terakhir menghasilkan rating supplier terbaik di PT.Pilaren dalam bentuk grafik batang.

\section{REFERENCES}

1. Esterlyan92.blogspot.com/2012/04/sikluspembelian.html

2. Giarratano, Joseph C. and Riley, Gary D. (2005). Expert Systems: Principles and Programming. Transcontinental. Louseville.

3. Kusrini.(2007) .'Konsep dan Aplikasi System Pendukung Keputusan",Andi Offset,

4. Kusumadewi \& Purnomo (2010). “Aplikasi Logika Fuzzy untuk Pendukung Keputusan Edisi 2", Graha Ilmu
5. Mc Leod, Raymond, (2011) "Sistem Informasi Management", Indeks

6. Negnevitsky, Michael. (2002). Artificial Inteligent: A Guide to Intelligent Systems. Biddles Ltd. Great Britain.

7. Siler, William and Buckley, James J. 2005. Fuzzy Expert System and Fuzzy Reasoning. John Wiley \& Sons, Inc. New Jersey.

8. Turban, Aronson, Ting Peng Liang , (2005) “ decision Support Systems And Intelligent Systems ( Sistem Pendukung Keputusandan Sistem Cerdas ), edisi 7, jilid 2, penerbit Andi.

9. Ahmed dan Ebrahim (2011) dengan judul A Fuzzy Decision Support System for Managementof Breast Cancer pada jurnal (IJACSA) International Journal of Advanced Computer Science and Applications, Vol. 2, No.3, March 2011

10. Ali, Adeli and Mehdi, Neshat. (2010). A Fuzzy Expert System for Heart Disease Diagnosis. Proceeding of International Multi Conference of Engineers and Computer Scientists. Vol. 1.

11. Dewi, Sudana and Putra (2012) Comparing Scoring and Fuzzy Logic Method for Teacher Certification DSS in Indonesia, IJCSI International Journal of Computer Science Issues, Vol. 9, Issue 6, No 2.

12. Djam, X.Y. and Kimbi, Y.H. (2011). Fuzzy Expert System for the Management of Hypertension. Proceeding of International Journal of Science and Technology. Vol. 12, No. 1, pp. 390-402.

13. Nasr, Rezaei dan Barmaki (2012) dalam International Journal of Computer Applications (0975 - 8887) Volume 59- No.7, December 2012 menggunakan Fuzzy Mamdani untuk pengambilan keputusan dalam menganalisis dan mengklasifikasi kualitas air tanah di propinsi Yazd -Iran

14. Niraj, Malay and Kumar, Shalendra. (2011). Modelling For Supplier through Fuzzy Logic. International Journal of Scientific \& Engineering Research. Vol. 2.

15. Guney and Sarikaya. (2009). Comparison of Mamdani and Sugeno Fuzzy Inference System Models for Resonant Frequency Calculation of Rectangular Microstrip Antennas. Proceeding of 
Progress In Electromagnetics Research B, Vol. 12, 81-104

16. Kermiche, S, et al. (2006). Takagi-Sugeno Based Controller for Mobile Robot Navigation. Proceeding of Journal of Applied Sciences 6 (8), page 1838-1844.

17. Ramezani, Maryam and Montazer, G.A. (2006). Design and Implementation of A Fuzzy Expert Decision Support System for Supplier Selection: Case Study in OIEC Iran (Oil Industrial Engineering and Construction). Proceeding of the 8th International Conference on Enterprise Information Systems: Databases and Info Systems Integration, page. 243-248. Shah, Satya. et al. 2007. Categorisation of Customer and Advisor in Contact Centres. International Journal of Computational Intelligence Research. Vol. 3, No.3, page. 193-204.

Surya Hendra Putra, lahir di Dolok Ilir, tanggal 30

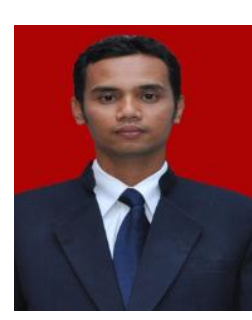
Desember 1979 jenis kelamin laki-laki. Memperoleh gelar Sarjana Komputer (S.Kom) dibidang Teknik Informatika dari STMIK Ganesha Bandungdan Sarjana Ekonomi ( SE )di bidang Ekonomi dari Universitas Muhammadiyah Sumatera Utara ( UMSU ), Serta Megister di STMIK Eresha Program studi Teknik Informatika jenjang Strata 2 (S2) Magister Komputer. Bekerja sebagai Dosen pada Politeknik Ganesha Medan. 